\title{
Efforts to Improve Learning Outcomes of Plant Parts Using Video Media in Class IV Students
}

\section{Noni Dyah Ardiani}

SD Negeri Tembarak

ardianinoni@gmail.com

\section{Article History}

accepted $14 / 11 / 2020$

\begin{abstract}
The purpose of this study was to improve student learning outcomes in science learning, especially material on plant parts and their functions. This research is a classroom action research (CAR) which is carried out in three learning cycles, each cycle consisting of 3 stages, namely planning, implementing, and reflecting. The subjects of this study were 20 grade students of SDN Tembarak for the 2020/2021 academic year. The data collection technique uses a test using the Googleform platform. Data analysis includes data reduction, data presentation, and drawing conclusions. Research shows that the use of instructional video media can improve student learning outcomes in science learning, especially material parts of plants and their functions in grade IV SDN Tembarak for the 2020/2021 academic year as evidenced by the percentage of completeness of learning outcomes in cycle I $70 \%$ and in cycle II 90\%. The conclusion from the results of this classroom action research is that there is an increase in student learning outcomes in the material parts of plants and their functions.
\end{abstract}

Keywords: Learning outcomes, instructional video media, students

\begin{abstract}
Abstrak
Tujuan penelitian ini adalah meningkatkan hasil belajar peserta didik pada pembelajaran IPA khususnya materi bagian-bagian tumbuhan dan fungsinya. Penelitian ini merupakan penelitian tindakan kelas (PTK) yang dilaksanakan dalam tiga siklus pembelajaran, setiap siklus terdiri dari 3 tahap yaitu perencanaan, pelaksanaan, dan refleksi. Subjek penelitian ini adalah peserta didik kelas IV SDN Tembarak tahun pelajaran 2020/2021 yang berjumlah 20 peserta didik. Teknik pengumpulan data menggunakan tes dengan menggunakan platform Googleform. Analisis data meliputi reduksi data, penyajian data, dan penarikan kesimpulan. Penelitian menunjukkan bahwa penggunaan media video pembelajaran dapat meningkatkan hasil belajar peserta didik pada pembelajaran IPA khususnya materi bagian-bagian tumbuhan dan fungsinya di kelas IV SDN Tembarak tahun pelajaran 2020/2021 yang dibuktikan dengan prosentase ketuntasan hasil belajar pada siklus I $70 \%$ dan pada siklus II $90 \%$. Kesimpulan dari hasil penelitian tindakan kelas ini adalah adanya peningkatan hasil belajar peserta didik pada materi bagian tumbuhan dan fungsinya.
\end{abstract}

Kata kunci: Hasil belajar, media video pembelajaran , peserta didik

Social, Humanities, and Education Studies (SHEs): Conference Series https://jurnal.uns.ac.id/shes

p-ISSN 2620-9284

e-ISSN 2620-9292 


\section{PENDAHULUAN}

Secara umum mutu pendidikan sekolah dasar, khususnya siswa kelas IV SD Negeri Tembarak pada mata pelajaran IPA pada materi bagian tumbuhan dan fungsinya masih rendah. Hasil pengamatan menunjukkan bahwa rendahnya hasil belajar tersebut pada dasarnya tidak lepas dari peran guru dalam melaksanakan proses pembelajaran di kelas daring. Hal ini erat kaitannya dengan media pembelajaran yang digunakan. Berdasarkan hasil wawancara dengan beberapa siswa kelas IV SD Negeri Tembarak bahwa pelajaran IPA pada materi bagian tumbuhan dan fungsinya dianggap sulit dan rumit. Oleh karena itu, guru memiliki peran yang sangat penting terutama yang menyangkut media yang digunakan dalam proses belajar yang juga akan ikut menentukan tinggi-rendahnya hasil dan tercapainya tujuan pembelajaran IPA pada materi bagian tumbuhan dan fungsinya. Memperhatikan pentingya penguasaan pelajaran IPA pada materi bagian tumbuhan dan fungsinya oleh peserta didik dan penyebab rendahnya hasil belajar peserta didik seperti yang telah diurai di atas, adalah penting untuk melakukan terobosan baru guna menciptakan suasana belajar yang efektif dan efisien apalagi dalam kondisi pembelajaran daring, sehingga dapat meningkatkan kualitas belajar peserta didik. Terobasan baru itu adalah pembelajaran yang cenderung membuat peserta didik menjadi lebih antusias dalam mengikuti pembelajaran.

Maka dari itu kewajiban para guru untuk menanamkan rasa senang terhadap materi pelajaran IPA dengan memberi rangsangan atau dorongan kepada mereka. Salah satu cara diantaranya adalah dengan memilih media pembelajaran yang sesuai era revolusi industry 4.0 yang berbasis TPACK dan HOTS, khususnya untuk anak kelas IV ( empat). Pembelajaran IPA yang menyenangkan, bervariasi, dan menggunakan media video dapat memotivasi anak dalam melaksanakan pembelajaran daring, sehingga proses pembelajaran berlangsung dengan baik dan akan berpengaruh terhadap peningkatan hasil belajar. Berdasarkan masalah di atas maka guru dalam menyampaikan pembelajaran harus dengan media. Media yang efektif dan efisien digunakan yaitu video. Dari permasalahan yang telah dipaparkan dapat disimpulkan bahwa hasil belajar IPA yaitu kemampuan menganalisis bagian tumbuhan dan fungsinya akan meningkat jika dalam proses pembelajarannya menggunakan media video. Hal inilah yang mendorong penulis untuk mengambil judul PTK Upaya Peningkatan Hasil Belajar Tema 3 Tentang Bagian Tumbuhan Menggunakan Media Video Pada Peserta Didik Kelas IV SDN Tembarak Tahun Pelajaran 2020/2021".

Menurut Supardi (2006), penelitian tindakan kelas adalah penelitian yang mampu menawarkan cara dan prosedur baru untuk memperbaiki dan meningkatkan profesionalisme pendidik dalam proses belajar mengajar di kelas dengan melihat kondisi siswa. Maka dari itu dalam kasus diatas sebagai upaya untuk meningkatkan hasil belajar peserta didik guru melakukan penelitian praktis dengan mengangkat sebuah masalah yang terjadi dalam pembelajaran, dengan cara menawarkan cara atau prosedur baru berupa menggunaan video pembelajaran untuk dapat memperbaiki dan meningkatkan hasil belajar sesuai dengan tujuan pembelajaran yang ingin dicapai.

Dalam melakukan penelitian tindakan kelas tidak bisa terlepas dari karakteristik dari penelitian tersebut yaitu, partisipasi dan kolaborasi antara peneliti dengan anggota kelompok sasaran. Penelitian tindakan kelas harus menunjukkan adanya perubahan ke arah perbaikan dan peningkatan secara positif. Apabila dengan tindakan justru membawa kelemahan, penurunan atau perubahan negatif, berarti hal tersebut menyalahi karakter penelitian tindakan kelas yang dilaksanakan.

Berdasarkan di atas, maka dapat dirumusan masalah yang diangkat sebagai berikut: (a). Apakah media video dapat meningkatkan hasil belajar peserta didik pada materi bagian tumbuhan dan fungsinya? (b). Bagaimana media video dapat meningkatkan hasil belajar peserta didik pada materi bagian tumbuhan dan fungsinya? 
Sesuai dengan rumusan masalah yang penulis uraikan diatas, penelitian ini bertujuan untuk meningkatkan hasil belajar peserta didik kelas IV pada materi bagian tumbuhan dan fungsinya tema III sub tema 1 menggunakan media vidio di SD Negeri Tembarak tahun pelajaran 2020/2021.

\section{METODE}

Penelitian ini merupakan penelitian tindakan kelas (PTK) kolaboratif yang dilaksanakan dalam tiga siklus. Setiap siklus terdiri dari tahap perencanaan, pelaksanaan, observasi, dan refleksi.siklus. Sikus I dilaksanakan pada 2 November 2020 dan siklus II dilaksanakan pada 9 November 2020. Subjek penelitian ini adalah peserta didik kelas IV SDN Tembarak tahun pelajaran 2020/2021 yang berjumlah 20 peserta didik.

Teknik pengumpula dan analisis data meliputi reduksi data, penyajian data, dan penarikan kesimpulan. Alat yang digunakan adalah tes dengan menggunakan platform Googleform untuk melihat hasil capaian peningkatan hasil belajar peserta didik.

Data yang dianalisis berupa data kuantitatif yaitu hasil belajar khususnya muatan pelajaran IPA pada materi bagian tumbuhan dan fungsinya.

\section{HASIL DAN PEMBAHASAN}

Berdasarkan analisis hasil penelitian yang telah diuraikan maka pembahasan pada penelitian ini sebagai berikut:

Hasil penelitian menunjukkan adanya peningkatan hasil belajar peserta didik dengan adanya implementasi media video pembelajaran yang dilakukan oleh guru.

Tabel 1. Peningkatan hasil belajar pesrta didik

\begin{tabular}{lllll}
\hline \multirow{2}{*}{ Nilai } & \multicolumn{2}{l}{ Siklus I } & \multicolumn{3}{l}{ Siklus II } \\
\cline { 2 - 5 } & $\mathrm{f}$ & $\%$ & $\mathrm{f}$ & $\%$ \\
\hline 100 & 4 & 20 & 5 & 10 \\
88 & 10 & 50 & 12 & 60 \\
75 & 2 & 10 & 2 & 25 \\
65 & 4 & 20 & 1 & 5 \\
Jumlah & 20 & 100 & 20 & 100 \\
Rata- & 72,1 & - & 89,7 & - \\
rata & 16 & - & 19 & - \\
Tuntas & & & & \\
\hline
\end{tabular}

Peningkatan hasil belajar peserta didik pada mupel IPA materi bagian tumbuhan dan fungsinya diukur dengan menggunakan teknik tes hasil belajar dengan instrument tes soal evaluasi yang disajian pada platform Googleform. Teknik pengumpulan data hasil belajar peserta didik diterapkan disetiap pertemuan setelah dilakukan proses pembelajaran. Aspek yang diukur yaitu aspek kognitif dengan menggunakan lavel kognitif menganalisi (C4), mengevaluasi (C5), dan mencipta (C6) yang diukur berdasarkan hasil evaluasi setelah mengikuti pembelajaran dengan pengimplementasian media video pembelajaran. 
Penggunaan media video pembelajaran dapat meningkatkan hasil belajar peserta didik di kelas IV SDN Tembarak secara signifikan. Pada hasil penilaian pembelajaran siklus I terdapat 4 dari 20 peserta didik yang belum mencapai KKM dengan rata-rata hasil belajar 72,1 . Setelah dilakukan perbaikan pada siklus II rata-rata hasil belajar pada siklus I meningkat menjadi 89,7.

Berdasarkan analisis hasil belajar peserta didik setelah pelaksanaan tindakan, dapat diambil kesimpulan bahwa penggunaan/ pengimplementasian media video pembelajaran dapat meningkatkan hasil belajar mupel IPA materi bagian tumbuhan dan fungsinya.

Hal ini sesuai dengan hasil penelitian yang dilakukan oleh Wuryanto yang membuktikan bahwa penggunaan video pembelajaran dapat meningkatkan aktifitas siswa dan berpengaruh terhadap hasil belajar peserta didik, pada mupel IPA materi bagian dan struktur tumbuhan di SD N Babadan kec. Bonang kab. Demak.

\section{SIMPULAN}

Penggunaan/pengimplementasian media video pembelajaran dapat meningkatkan prestasi belajar peserta didik karena, dengan media ini peserta didik diajak selalu melihat, mendengar dan memahami tentang bagian serta fungsi tumbuhan dengan asik dan menyenangkan. Media video pembelajaran dapat memotivasi peserta didik kelas IV SDN Tembarak tahun pelajaran 2020/2021 untuk semangat belajar sehingga hasil belajar juga mengalami peningkatan. Hal ini dapat dilihat dari peningkatan nilai rata-rata pada siklus I yaitu 72,1 mengalami peningkatan pada perbaikan pembelajaran disiklus II menjadi 89,7.

\section{DAFTAR PUSTAKA}

Ashar Arsyad. (2003). Media Pembelajaran. Jakarta : PT. Raja Grafindo Persada. (2006). Media Pembelajaran. Jakarta : PT. Raja Grafindo Persada. (2009). Media Pembelajaran. Jakarta : PT. Raja Grafindo Persada

Arikunto, Suhardjono dan Supardi. 2006. Penelitian Tindakan Kelas. Jakarta: Bumi Aksara.

Aqib, Zainal, dkk. 2011. Penelitian Tindakan Kelas untuk Guru SD, SLB, dan TK. Bandung: Yrama Widya.

Dwi Yunita\& Astuti Wijayanti. (2017). Pengaruh Media Video Pembelajaran Terhadap Hasil Belajar Ipa Ditinjau Dari Keaktifan Siswa. SOSIOHUMANIORA - Vol.3, No.2, Agustus 2017 - Jurnal LP3M - Universitas Sarjanawiyata Tamansiswa Yogyakarta

Retrieved from : https://core.ac.uk/download/pdf/230370339.pdf

Mulyatiningsih, Endang. 2011. Metode Penelitian Terapan Bidang Pendidikan. Bandung: Alfabeta.

Padmono, Y. 2010. Kekurangan dan kelebihan, Manfaat Penerapan PTK. Online: edukasi.kompasiana.com.

Sadiman, dkk. (2009). Media Pendidikan: Pengertian, Pengembangan, dan pemanfaatannya. Jakarta: Rajawali Press.Pengertian Hasil Belajar | Definisi, Fungsi, Tujuan, Faktor [Lengkap]. https://www.zonareferensi.com/pengertianhasil-belajar/

Wuryanto. (2015/2016). Meningkatkan Prestasi Belajar IPA Dengan Media Video Dan Metode Stad Semester 1 Kelas Iv Sdn Babadan Tahun 2015/2016. Jurnal Refleksi Edukatika Vol. 6 No. 2 Juni 2016. 